\title{
KT5926 Selectively Inhibits Nerve Growth Factor-Dependent Neurite Elongation
}

\author{
Kenneth K. Teng and Lloyd A. Greene \\ Department of Pathology and Center for Neurobiology and Behavior, Columbia University, College of Physicians and \\ Surgeons, New York, New York 10032
}

\begin{abstract}
We have examined the effects of the protein kinase inhibitor KT5926 on NGF-promoted responses in PC12 and PC12-C41 cells (a subclone of the parental cell line). Our findings reveal that this compound specifically and reversibly prevents the NGF-induced outgrowth and regeneration of neurites. In addition, neurites of NGF-pretreated cells cease further elongation upon exposure to KT5926. However, preexisting neurite networks in the cultures remain intact in the presence of the drug. The inhibition of neuritic growth appears to occur at least in part at the level of growth cones since KT5926 also causes these structures to collapse and inhibits NGFpromoted reactivation of NGF-deprived growth cones. Although KT5926 is an analogue of K-252a, which blocks all responses to NGF, it does not affect other NGF-elicited cellular responses examined, including NGF-dependent priming of cells, gp 140 prototth autophosphorylation, immediate-early gene induction, and phosphorylation of several known cytoskeletal proteins (MAP 1.2/1B, chartin MAPs, and $\beta$-tubulin). However, phosphate incorporation into a cytoskeletally localized $58 \mathrm{kDa}$ phosphoprotein, designated pp58, is selectively reduced in KT5926-treated cultures ( \pm NGF). Although KT5926 is an in vitro inhibitor of myosin light chain kinase and calmodulin-dependent protein kinase II, inhibition of these two kinase activities by ML-9 and KN-62, respectively, applied alone or together, does not mimic the effects of KT5926 on neurite growth and on pp58 phosphorylation. Taken together, our findings suggest that KT5926, via a previously unidentified protein kinase inhibitory activity, differentially interferes with NGF-promoted growth cone function and consequently affects neuritic outgrowth. This compound should therefore be a useful tool for dissecting the mechanism of NGF actions and affords a means to identify phosphoproteins that play specific roles in neurite growth/elongation.
\end{abstract}

[Key words: cytoskeleton, growth cone, $K$-252a derivative, neuronal differentiation, PC12 cells, PC12-C41 cells, protein kinase inhibitor, signal transduction]

\footnotetext{
Received Aug. 2, 1993; revised Oct. 7, 1993; accepted Oct. 19, 1993.

Wc thank Drs. Wilfredo Mellado and David Loeb for the gift of bovine MAPs and advice on immunoprecipitation of gpl $40^{\text {prototrk, }}$, respectively. We are also grateful to Dr. David Kaplan for generously providing anti-gp 140 protork and anti-phosphotyrosine antisera. This work was supported by grants from the NIH-NINDS.

Correspondence should be addressed to Kenneth K. Teng, Department of Pathology, Columbia University, College of Physicians and Surgeons, 630 West 168 Street, New York, NY 10032.

Copyright $(1994$ Society for Neuroscience $0270-6474 / 94 / 142624-12 \$ 05.00 / 0$
}

NGF is the prototypic and best studied example of the neurotrophin family of polypeptide growth factors (reviewed by LeviMontalcini and Angeletti, 1968; Ebendal, 1992). NGF exhibits profound trophic and differentiation-promoting effects on specific neuronal populations in both the PNS and CNS (reviewed by Levi-Montalcini and Angeletti, 1968). However, the underlying molecular mechanisms by which NGF and other neurotrophins exert their actions on target neurons remain largely undefined.

The rat pheochromocytoma PC1 2 cell line (Greene and Tischler, 1976) is an NGF-responsive model system that has been uscful for studying the undcrlying mechanisms of NGF actions (reviewed by Halegoua et al., 1991; Levi and Alemá, 1991). PC1 2 cells proliferate in serum-containing culture medium, and in many respects resemble their non-neoplastic adrenal chromaffin cell counterparts. When exposed to NGF, however, these cells withdraw from the cell cycle and gradually adopt many properties that are characteristic of mature sympathetic neurons (Greene and Tischler, 1982). The most dramatic aspect of this response is the extension of long, axon-like neurites with actively motile growth cones (reviewed by Aletta et al., 1990). The acquisition of a "neuronal" phenotype by $\mathrm{PCl} 2$ cells requires both transcription-dependent and -independent cellular responses to NGF (Burstein and Greene, 1978; Greene, 1984). Transcription-dependent events include upregulation of selective cytoskeletal proteins (Leonard et al., 1988; Noble et al., 1989; Weinberger et al., 1993) and other neural markers (Dickson et al., 1986; Prentice et al., 1987), while relevant transcription-independent actions include regulation of cytoskeletal protein phosphorylation (Greene et al., 1983; Black et al., 1986; Aletta and Greene, 1987; Aletta et al., 1988, 1989), promotion of growth cone motility (Seeley and Greene, 1983; Connolly et al., 1985; Aletta and Greene, 1988), and rapid regeneration of neurites (Burstein and Greene, 1978; Greene et al., 1982). Stimulation of neuritogenesis by NGF is therefore a complex phenomenon composed of multiple individual responses (Aletta et al., 1990).

Pharmacological agents that inhibit or mimic specific aspects of NGF actions have been particularly useful for dissecting the pleiotropic effects of this factor and thereby further understanding the NGF mechanism. Here we report that the protein kinase inhibitor KT5926 (Nakanishi et al., 1990; Hashimoto et al, 1991) prevents the outgrowth of neurites from a PC12 cell line but does not interfere with other NGF-regulated events, such as priming, rapid gene induction, and phosphorylation of microtubule-associated proteins (MAPs). Our findings suggest that KT5926 may act to inhibit elongation of neurites differentially at least in part by suppressing NGF-promoted motility of growth 
cones. This compound should aid future analysis of the mechanism by which NGF regulates neuritic outgrowth.

\section{Materials and Methods}

Reagents and materials. NGF (2.5S) was purified from adult mouse submaxillary glands according to Mobley et al. (1976) and used at concentrations of $50-100 \mathrm{ng} / \mathrm{ml}$. The protein kinase inhibitors KT5926, $\left(8 R^{*}, 9 S^{*}, 11 S^{*}\right)-(-)$-9-hydroxy-9-methoxycarbonyl-8-methyl-14-npropoxyl-2,3,9,10-tetrahydro-8, 11 -epoxy, $1 H, 8 H, 11 H-2,7 \mathrm{~b}, 1$ la-triazadibenzo $[a, g]$ cycloocta[cde]trinden-1-one, and $\mathrm{K}-252 \mathrm{a}$ were purchased from Kamiya Biomedical Company, Thousand Oaks, CA, and were dissolved in dimethyl sulfoxide (DMSO) as concentrated stocks ( $5 \mathrm{~mm}$ and $1 \mathrm{mM}$, respectively). Inhibitors for myosin light chain kinase (MLCK) (ML-9) and calmodulin-dependent protein kinase II (CamKII) (KN-62) were purchased from Seikagaku America, Inc., Rockville, MD, and dissolved in DMSO (stock concentration; $10 \mathrm{~mm}$ for both inhibitors). Polyclonal antiserum against gp140 protork (203-9; Soltoff et al., 1992) and monoclonal anti-phosphotyrosine antibody 4G10 (Kaplan et al., 1990) were generous gifts from Dr. David Kaplan (NCI, Frederick, MD). Radiolabeling reagents were obtained from DuPont-New England Nuclear, Boston, MA. Protein concentration determination was carried out according to Bradford (1976) using reagents purchased from BioRad Laboratories, Richmond, CA.

Cell cultures. PC12-C41 cells are clonal variants of the PC12 cells that elaborate more abundant neurites in the presence of NGF. The establishment and characterization of the PC12-C41 cell line have been described elsewhere (Teng et al., 1993).

$\mathrm{PC1} 12$ and $\mathrm{PC12}-\mathrm{C} 41$ cells were cultured on collagen-coated dishes in RPMI 1640 medium supplemented with $10 \%$ heat-inactivated horse scrum and 5\% fetal bovine serum (complete medium; Greene et al., 1987, 1991). For NGF treatment, cultures were plated at low density $\left(5 \times 10^{5}\right.$ cells per $35 \mathrm{~mm}$ dish or $1-2 \times 10^{6}$ cells per $100 \mathrm{~mm}$ dish) in complete medium and NGF. Where applicable, various inhibitors were added directly (from concentrated stocks) to the medium. The carrier DMSO alone (up to $0.2 \%$ in complete medium) has no demonstrable effect on $\mathrm{PC} 12$ or PC12-C41 cell cultures.

Measurement of neurite outgrowth. Neurite-bearing cells were scored at high magnification $(320 \times)$ as previously described (Greene and Tischler, 1976). Only processes greater than 2 cell body diameters in length (i.e., about $20 \mu \mathrm{m}$ ) were considered neurites, and cells in the center of clumps that could not be adequately discerned were excluded. For each culture condition, at least 100 cells from randomly chosen fields were scored.

Neurite lengths were measured by the use of an eyepiece equipped with a calibrated micrometer (Greene et al., 1982) and 20 random neurites were assessed per culture condition.

Neurite regeneration assays (see Figs. $2 B, 3 B$ ) were carried out with NGF-primed cells (with or without KT5926 treatment during priming) as previously described (Burstein and Greene, 1978). At least 100 cells/ cell clumps per culture condition were scored for their abilities to regenerate neurites.

Assessment of growth cone morphology. Cells were fixed (without prior removal of the culture medium) in paraformaldehyde by rapid, dropwise addition of $2 \mathrm{vol}$ of $4 \%$ paraformaldehyde/PBS (prewarmed to $37^{\circ} \mathrm{C}$ ) to 1 vol of the culture medium. The cultures were allowed to fix for 1 $\mathrm{hr}$ at $37^{\circ} \mathrm{C}$ before examination with phase-contrast optics under high magnification $(320 \times)$ ). The morphologies of individual growth cones were classified cither as "cxtended" or "collapsed" (as shown in Fig. $5 A, B$, respectively). The percentages of extended growth cones under various culture conditions were determined on coded samples and were scored blind by the observer. At least 100 growth cones were examined per culture condition.

Metabolic labeling and subcellular fractionation. Metabolic radiolabeling of cell cultures with $50-300 \mu \mathrm{Ci}$ of ${ }^{32} \mathrm{P}$-orthophosphate was performed in $35 \mathrm{~mm}$ dishes in $1 \mathrm{ml}$ of modified HEPES-buffered KrebsRinger solution by incubation for $2 \mathrm{hr}$ at $37^{\circ} \mathrm{C}$ (Black et al., 1986). Where applicable, the labeling medium contained NGF with or without various inhibitors.

Total cellular extracts were prepared by directly harvesting the cells in $1 \times$ SDS sample buffer (Laemmli, 1970) and boiling for $10 \mathrm{~min}$. Subcellular fractionations were performed on ${ }^{32} \mathrm{P}$-labeled cells attached to $35 \mathrm{~mm}$ culture dishes to yield a Triton $\mathrm{X}-100$-soluble fraction and a $\mathrm{Ca}^{2+}$-extractable/microtubule-enriched fraction as previously de- scribed (Solomon et al., 1979; Aletta and Greene, 1987; Teng and Greene, 1993).

Sample analyses by SDS-PAGE were carried out on $5 \%, 7.5 \%$, or $10 \%$ polyacrylamide or, where applicable, $5-10 \%$ polyacrylamide gradient gels. Purified bovine microtubules and MAPs, generously provided by Dr. Wilfredo Mellado, Columbia University, New York, NY, were included with molecular mass standards (Bio-Rad Laboratories) to indicate the positions of tubulins and MAP $1 \mathrm{~B} / 1.2$. The gels containing ${ }^{32} \mathrm{P}$-labeled proteins were fixed, stained, dried, and then exposed to Kodak XAR-5 x-ray film.

Analysis of gp 140 protork tyrosine phosphorylation. Cell extracts were prepared and equal amounts of protein were subjected to immunoprecipitation with antiserum 203-9 against gp1 40 protork (Soltoff et al., 1992; used at 1:200 dilution) as described by Loeb et al. (1992). The immunoprecipitates were resolved by SDS-PAGE on a $7.5 \%$ polyacrylamide gel and transferred unto supported nitrocellulose (S \& S, Keene, NH) according to Towbin et al. (1979). The blot was then probed with antiphosphotyrosine antibodies $4 \mathrm{G} 10$ (used at $1: 1$ dilution in 3\% BSA/PBS; kindly provided by Dr. David Kaplan, NCI, Frederick, MD) and the tyrosine-phosphorylated gp $140^{\text {protork }}$ was detected with $350 \mathrm{nCi}$ of ${ }^{125} \mathrm{I}$ labeled goat anti-mouse IgG per milliliter of 3\% BSA/PBS. Autoradiographic images were obtained by exposing the blot to Kodak XAR-5 $\mathrm{x}$-ray film with an intensifying screen at $-80^{\circ} \mathrm{C}$.

Northern blotting analysis. Total cellular RNA was isolated according to Chomczynski and Sacchi (1987). RNA was subjected to electrophoresis at $150 \mathrm{~V}$ on $1 \%$ agarose-formaldehyde gels and transferred to GeneScreen Plus membrane following the manufacturer's protocol (DuPont-New England Nuclear). The ${ }^{32} \mathrm{P}$-labeled probes for c-fos (Curran et al., 1982) and Tis-1 (Kujubu et al., 1987) were prepared by random priming reactions (Boehringer-Mannheim, Indianapolis, IN). Blots were hybridized overnight at $37^{\circ} \mathrm{C}$ with the radiolabeled probe and were washed at high stringency as described for GeneScreen Plus membrane. The equality of sample loading was verified by ethidium bromide staining.

\section{Results}

Compound KT5926 inhibits NGF-induced neurite outgrowth, but not priming

To examine the potential effects of the protein kinase inhibitor KT5926 on neurite outgrowth, PC12 and PC12-C41 cells were exposed to NGF in the presence or absence of this compound. PC12-C41 cells are a clonal variant line of $\mathrm{PC} 12$ cells that show significantly enhanced neuritogenic potential, but otherwise generally similar behavior (Teng et al., 1993). Figure $1 B$ shows that in the absence of KT5926, NGF-treated PC12-C41 cells elaborate abundant neurites. In contrast, as shown in Figure 1D, 5 $\mu \mathrm{M}$ KT5926 substantially inhibits the formation of the neurite network even after the same long-term exposure (11 d) to NGF. This inhibition of neuritc outgrowth was observed at all times of exposure to this drug (from $1 \mathrm{~d}$ to 2 weeks; data not shown). Note that KT5926 applied alone appears to induce a slight flattening of the cells (Fig. 1C). Comparable observations were achieved with PCl2 cells (not shown). Because of its greater neuritogenic capacity, the bulk of the subsequent studies were carried out with the PC12-C41 cell subclone.

The inhibitory effect of KT 5926 on neuritogenesis was quantified and is shown in Figure 2. The data in Figure $2 A$ show that only $3-5 \%$ of the cells treated with $5 \mu_{\mathrm{M}} \mathrm{KT} 5926$ were neurite bearing after $11 \mathrm{~d}$ of treatment with NGF, whereas all of the control NGF-treated cells possessed neurites. To determine whether the inhibition of neurite growth by KT5926 is a nonspecific cytotoxic effect or is direct and reversible, a portion of the cultures treated with NGF plus KT5926 for $11 \mathrm{~d}$ were washed free of the compound (by rinsing three times with complete medium) and re-fed with complete medium containing only NGF, and the percentage of neurite-bearing cells was measured $3 \mathrm{~d}$ later. The results (Fig. $2 A$ ) reveal that $80-90 \%$ of the cells extended neurites after washout of the inhibitor, indicating that 

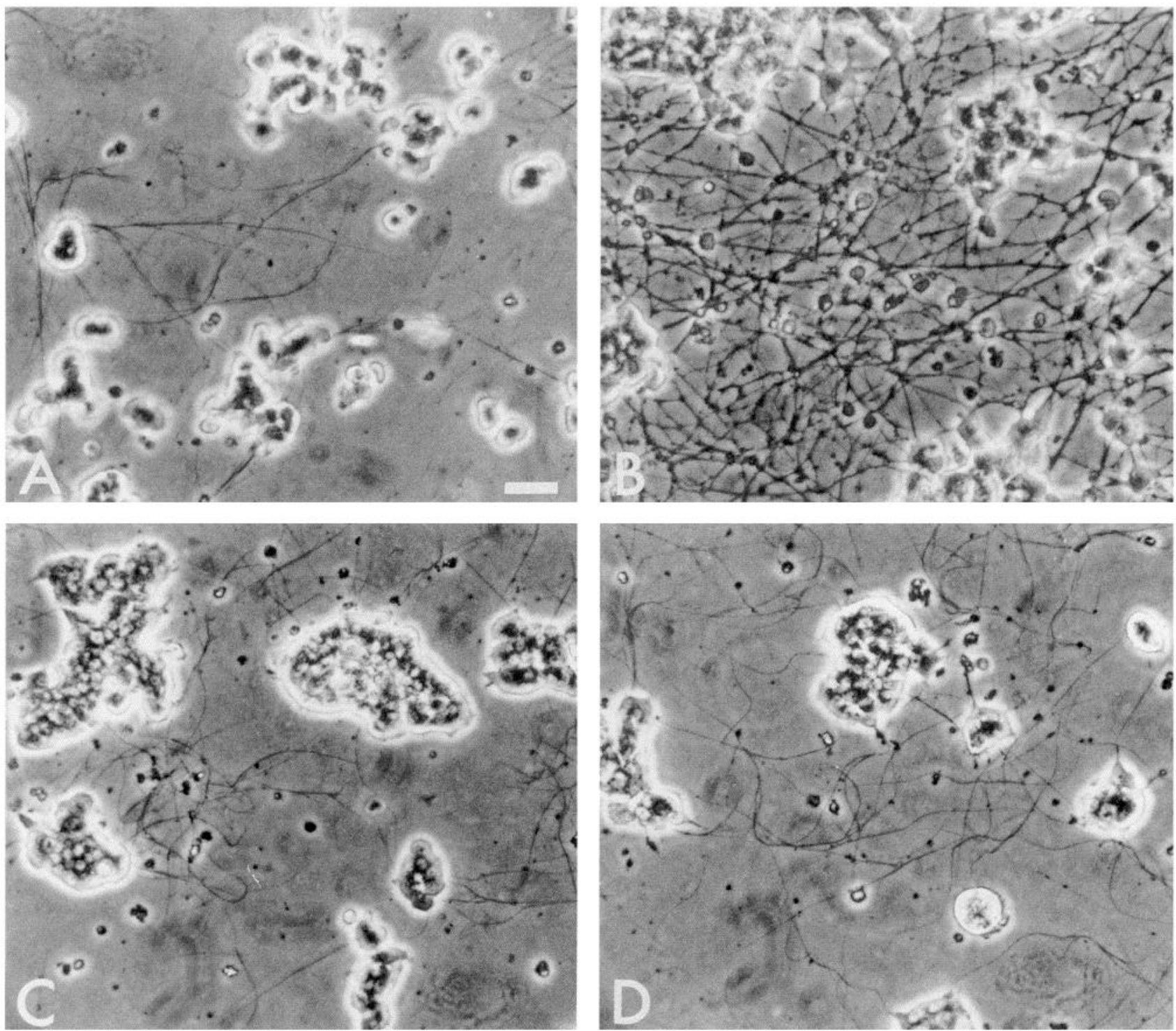

Figure 1. Phase-contrast micrographs of PC12-C41 cell cultures treated with or without NGF and/or KT5926. PC12-C41 cells were maintained in culture for $11 \mathrm{~d}$ without NGF $(A)$, with NGF $(100 \mathrm{ng} / \mathrm{ml})$ alone $(B)$, with $5 \mu \mathrm{M} \mathrm{KT} 5926$ alone $(C)$, or with $100 \mathrm{ng} / \mathrm{ml} \mathrm{NGF}$ plus $5 \mu \mathrm{M} \mathrm{KT} 5926$ (D). The thin curly fibrils that appear at the bottom of the cultures (in $A, C, D$ ) are strands of collagen substrate. Scale bar, $50 \mu \mathrm{m}$.

KT5926 treatment is reversible and does not produce nonspecific reduction of cell viability. Since naive cells that were treated for a comparable period with $5 \mu \mathrm{M}$ KT5926 alone did not extend neurites after washout of the drug (data not shown), the removal of KT5926 per se does not cause neurite extension.

We have previously shown that the time course of NGFdependent neuritogenesis by naive PC12 and PC12-C41 cells exhibits an initial lag period followed by a prolonged rate of neurite appearance (Greene and Tischler, 1976; Teng et al., 1993). In contrast, however, after NGF pretreatment, these cells regenerate long neurites after only 16-18 hr of NGF exposure (Burstein and Greene, 1978; Teng et al., 1993). The observation that a large proportion of the cells treated with both KT5926 and NGF rapidly extended neurites with no apparent lag time after removal of the inhibitor (Fig. $2 A$ ) suggested that the cells may be "primed" by NGF even in the continuous presence of KT5926. That is, while the drug may interfere with neurite outgrowth per se, it does not appear to affect the mechanisms that permit the cells to undergo NGF-dependent accumulation of materials needed to construct neurites (Greene, 1984). To examine this issue directly, replicate cultures were pretreated with either NGF alone or with NGF plus $5 \mu$ M KT5926 for 14 $\mathrm{d}$ and then subjected to a neurite regeneration assay in the presence or absence of NGF and KT5926 (Fig. 2B). Consonant with prior findings (Burstein and Greene, 1978; Teng et al., 1993), cells pretreated with NGF alone rapidly regenerated neurites in an NGF-dependent manner. Moreover, a substantial number of cells pretreated with both NGF and KT5926 rapidly generated neurites when passaged into NGF-containing medium alone. Finally, KT5926 also substantially inhibited neurite regeneration/generation by cells primed with either NGF alone or with NGF plus the drug. Thus, KT5926 blocks regeneration as well as initiation of neurites, but does not appear to suppress NGF-dependent priming.

We next examined the dose dependence of inhibition of neurite growth by KT5926. Figure $3 A$ reveals that KT5926 inhibits 

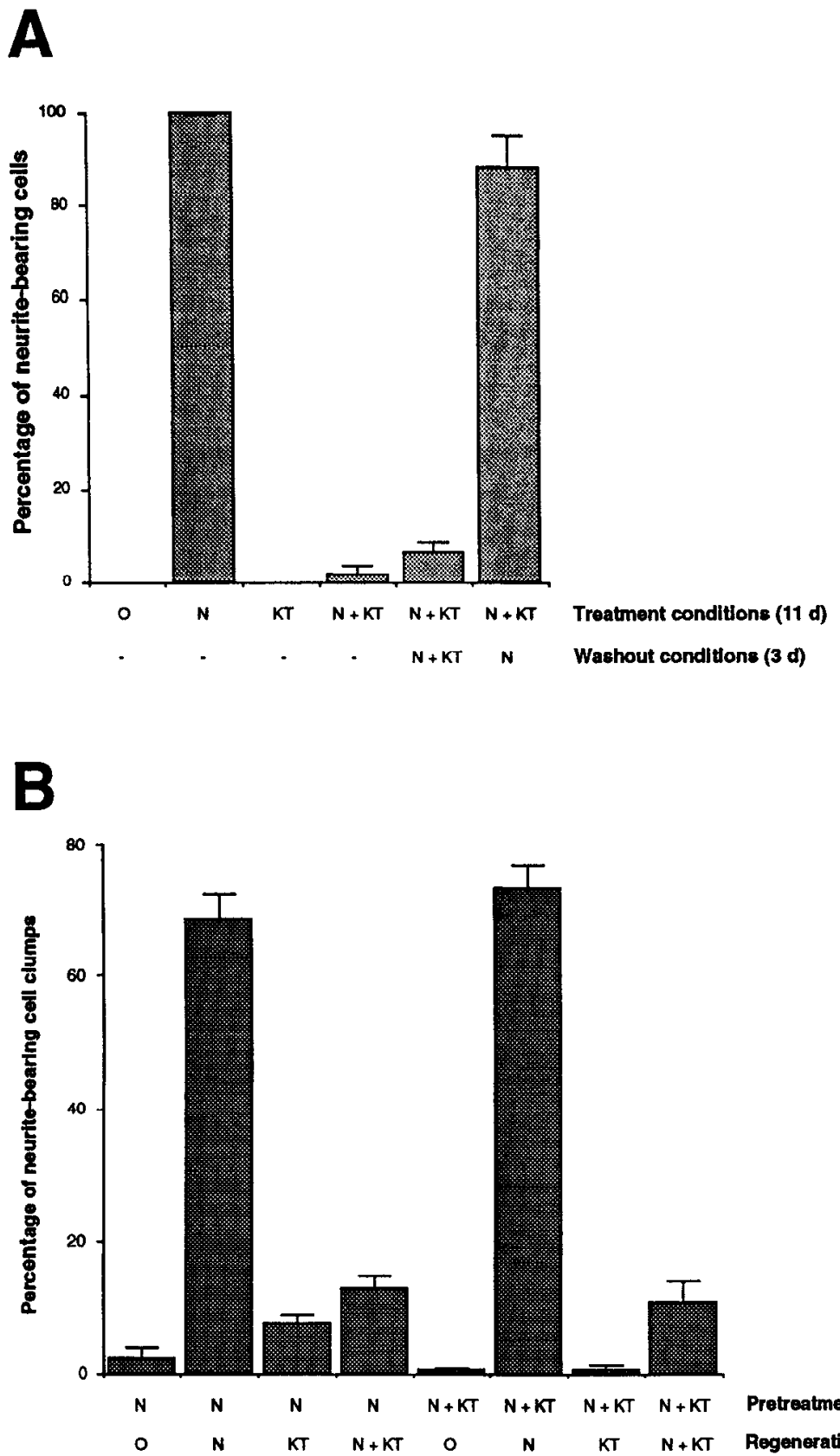

NGF-induced neurite outgrowth from naive cells in a dosedependent manner and that the half-maximal concentration for inhibition $\left(\mathrm{IC}_{30}\right)$ is $\approx 3 \mu \mathrm{M}$. Cytotoxicity was apparent only in those cultures that were exposed to $10 \mu \mathrm{M}$ KT5926 for more than 1 week (data not shown). A dose-dependent inhibition of neurite outgrowth by KT5926 was also observed in cultures maintained in serum-free medium, but the required concentrations were about 10 -fold higher (data not shown). Finally, we determined the KT5926 dose dependence for inhibition of neurite regeneration by NGF-primed cells. The results, as shown in Figure $3 B$, also indicate an $\mathrm{IC}_{50}$ of about $3 \mu \mathrm{M}$.

\section{KT5926 blocks the actions of NGF on neurite elongation and growth cone morphology}

Since KT5926 appears to affect differentially the ability of NGF to induce neurite outgrowth but not priming, experiments were
Figure 2. Effects of KT5926 on NGFdependent neurite outgrowth and priming. $A$, Quantitation and reversibility of the inhibitory effect of KT5926 on neurite outgrowth. Replicate cultures of PC12-C41 cells received either no treatment $(O), 100 \mathrm{ng} / \mathrm{ml} \mathrm{NGF}$ alone $(N), 5 \mu \mathrm{M}$ KT5926 alone $(K T)$, or 100 $\mathrm{ng} / \mathrm{ml} \mathrm{NGF}$ and $5 \mu \mathrm{M}$ KT5926 $(N+$ $K T)$ as indicated. The percentages of neurite-bearing cells under each culture condition were determined after $11 \mathrm{~d}$. A portions of the cultures treated with NGF and KT5926 were then either treated with NGF and $5 \mu \mathrm{M} \mathrm{KT} 5926$ $(N+K T)$ or were washed free of the inhibitor and maintained in complete medium containing only NGF $(N)$. The proportions of neurite-bearing cells were assessed $3 \mathrm{~d}$ later as indicated (far right two columns of the graph). Error bars represent ranges of measurements on duplicate cultures. Comparable results were obtained in three additional independent experiments. $B$, KT5926 effects on priming and neurite regeneration. $\mathrm{PC1}-\mathrm{C} 41$ cells were pretreated as indicated (pretreatment conditions) with either $100 \mathrm{ng} / \mathrm{ml} \mathrm{NGF}(N)$ or $100 \mathrm{ng} /$ ml NGF plus $5 \mu \mathrm{M}$ KT5926 $(N+K T)$ for $14 \mathrm{~d}$. Both cultures were then replated as indicated (regeneration conditions) in either complete medium $(O)$ or complete medium containing $100 \mathrm{ng} /$ $\mathrm{ml} \mathrm{NGF}(N)$ and, as indicated, in the presence or absence of $5 \mu \mathrm{M}$ KT5926 $(K T)$. The percentages of neurite-bearing cells/cell clumps under each culture condition were determined $24 \mathrm{hr}$ later. Values represent mean \pm SEM of triplicate cultures. The experiment was repeated three times with comparable results.
Pretreatment conditions

Regeneration conditione performed to determine whether this compound exhibits specific aspects of the former. We therefore added KT5926 (2.5 and $5 \mu \mathrm{M})$ to cultures with preexisting neurites in the continued presence of NGF and measured the rate of process extension. As shown in Figure 4, although KT5926 does not cause retraction of preexisting neurites, it substantially prevents their further elongation. Note that the inhibitory effect is apparent even after $1 \mathrm{~d}$ of exposure to this compound. Consistent with the data in Figure 3, the blockade of neurite growth by KT5926 is dose dependent in that a lower concentration of this compound is less effective.

Past studies have shown that NGF rapidly regulates growth cone morphology and motility (Seeley and Greene, 1983; Connolly et al., 1985, 1987; Aletta and Greene, 1988). In the presence of NGF, growth cones exhibit an extended, fan-shaped conformation and advance, whereas after NGF withdrawal they 
A

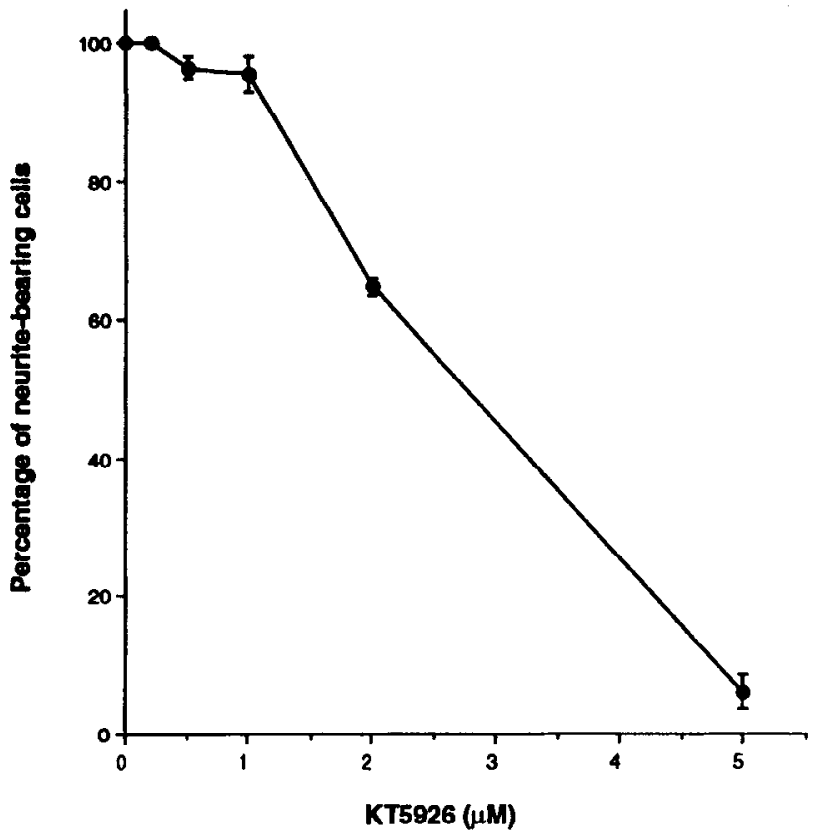

B

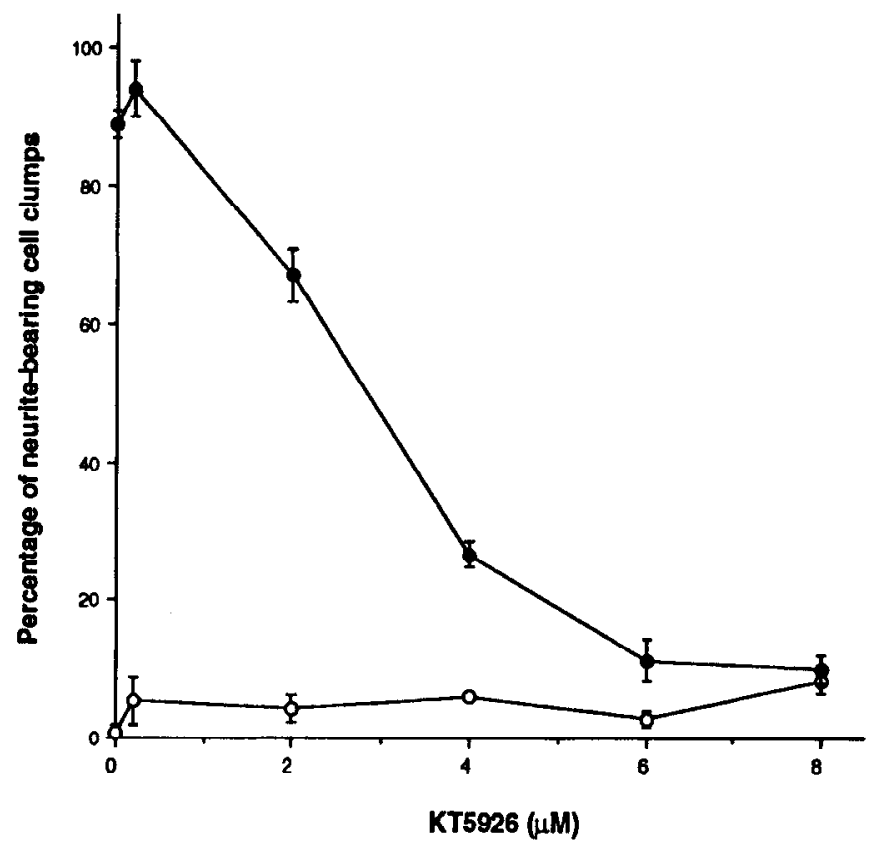

Figure 3. Dose-response relationship for inhibition of NGF-promoted neurite initiation $(A)$ and regeneration $(B)$ by KT5926. $A$, Replicate cultures of PC12-C41 cells were treated with $100 \mathrm{ng} / \mathrm{ml} \mathrm{NGF}$ in the absence or presence of the indicated concentrations of KT5926, and the percentages of neurite-bearing cells under each treatment condition were determined $12 \mathrm{~d}$ later. Error bars represent the ranges of measurements on duplicate cultures. An additional experiment yielded similar results. B, PC12-C41 cells were primed with $100 \mathrm{ng} / \mathrm{ml} \mathrm{NGF}$ for $24 \mathrm{~d}$ and subjected to a neurite regeneration assay in the absence (open circles) or presence (solid circles) of $100 \mathrm{ng} / \mathrm{ml} \mathrm{NGF}$ with the indicated concentrations of KT5926. Replicate cultures were scored $24 \mathrm{hr}$ later for the proportion of neurite-bearing cells/cell clumps. Error bars represent the ranges of measurements on duplicate cultures. Comparable results were obtained in an additional independent experiment.

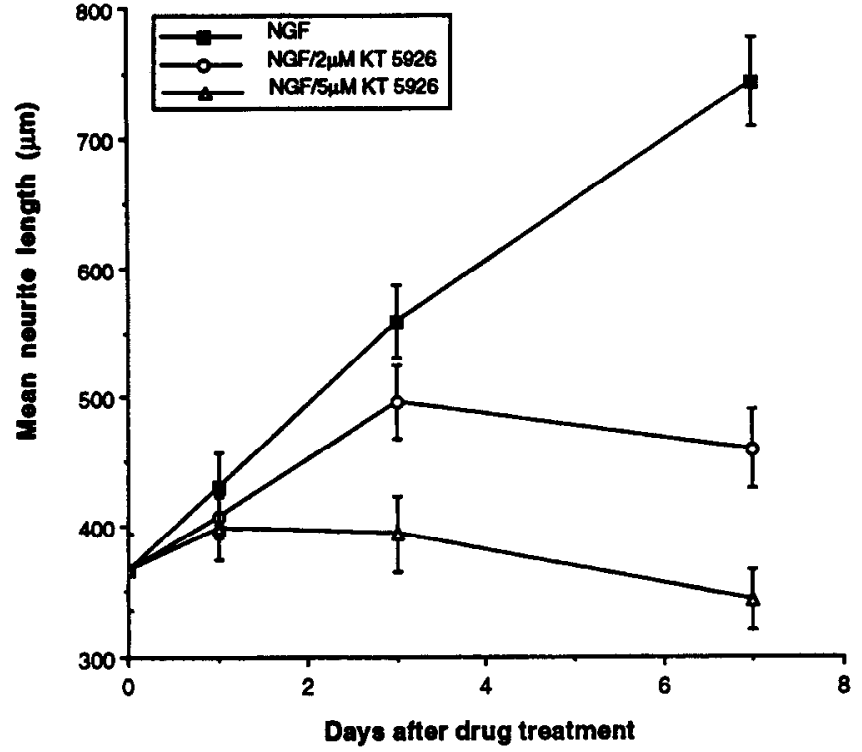

Figure 4. Effects of KT5926 on neurite elongation. Replicate cultures of PC12-C41 cells were primed with $100 \mathrm{ng} / \mathrm{ml} \mathrm{NGF}$ for $9 \mathrm{~d}$ (day 0 on $\mathrm{x}$-axis). Cultures were then maintained in NGF-containing culture medium either with no additional additive (squares) or with $2.5 \mu \mathrm{M}$ (circles) or $5 \mu \mathrm{M}$ (triangles) KT5926. Neurite lengths from each culture were measured at the indicated time points (days after drug treatment). Values represent means $\pm \operatorname{SEM}(n=20)$. Two additional experiments yielded similar results. collapse into blunt-ended morphologies and cease movement (Seeley and Greene, 1983; Connolly et al., 1985, 1987; Aletta and Greene, 1988). Moreover, readdition of NGF to collapsed growth cones results in their rapid reattainment of a spread morphology and of motility (Seeley and Greene, 1983; Connolly et al., 1987; Aletta and Greene, 1988). To address whether KT5926 might exert its effects on neurite growth at least in part at the level of the growth cone, cultures were preincubated with NGF for $8 \mathrm{~d}$ and a portion were then treated overnight with NGF and KT5926. Scoring of the growth cones for extended or collapsed morphologies revealed that $80-90 \%$ were extended in cultures with NGF alone (Fig. 5A,C), whereas $90 \%$ collapsed in cultures exposed to NGF and the drug (Fig. 5B,C). Parallel cultures (after overnight NGF deprivation) were also assessed for the effects of NGF readdition ( \pm KT5926). As shown in Figure $5 C$, readdition of NGF caused the anticipated return of extended growth cones, while exposure to KT5926, in either the presence or absence of NGF, completely prevented this effect. Although the neurites ceased elongation (Fig. 4) and appeared "beady" (Fig. 5B) after KT5926 treatment, the existing neurite network in the cultures remained intact for at least a week of exposure to KT5926 plus NGF (data not shown). Taken together, the above findings indicate that KT5926 blocks NGFpromoted neurite generation and regeneration by interfering with process outgrowth, and does so at least in part at the level of the growth cone. 

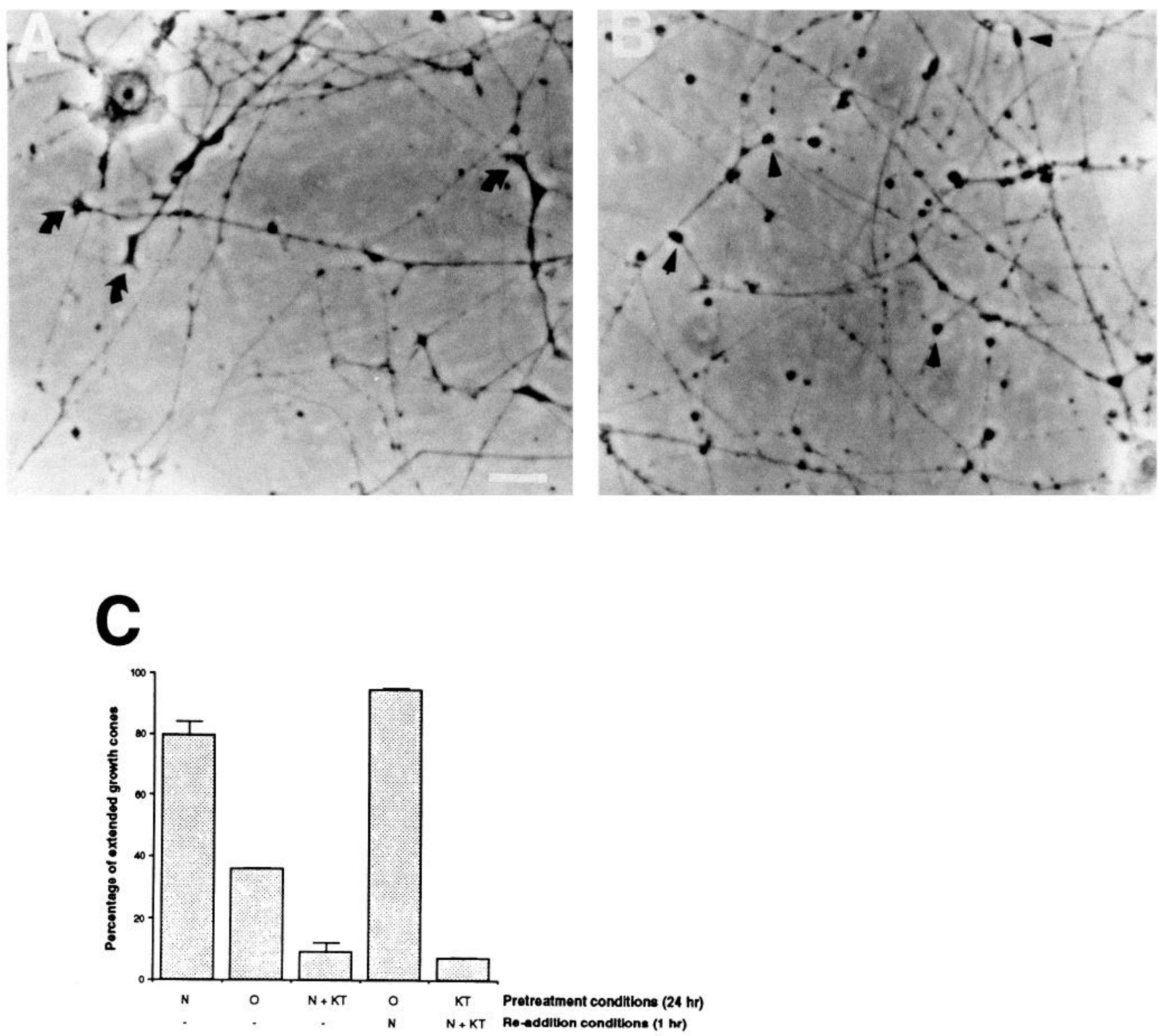

Figure 5. Effect of KT5926 on growth cone morphology. $A$ and $B$, Replicate PC12-C41 cultures were treated with $100 \mathrm{ng} / \mathrm{ml}$ NGF for $9 \mathrm{~d}$ without $(A)$ or with $(B) 5 \mu \mathrm{M}$ KT5926 present for the last $24 \mathrm{hr}$. Phase-contrast photomicrographs of growth cones show that most are extended in control NGF-treated cultures $(A$, arrows) whereas most are collapsed after $24 \mathrm{hr}$ exposure to KT5926 (B, arrowheads). Scale bar, $20 \mu \mathrm{m}$. $C$, Quantitation of the effect of KT5926 on growth cone morphology. Replicate PC12-C41 cultures were primed with NGF for $8 \mathrm{~d}$. They were then washed three times with NGF-free complete medium and refed with complete medium with $(N)$ or without $(O)$ NGF and with or without $5 \mu \mathrm{M}$ KT5926 $(K T)$ as indicated (pretreatment conditions). A portion of the cultures (NGF-treated, NGF-deprived, and NGF-treated plus KT5926) were fixed 24 hr later as described in Materials and Methods. The remaining cultures (NGF-deprived, and NGF-deprived but KT5926-treated) were cultured for an additional hour in the presence of $100 \mathrm{ng} / \mathrm{ml} \mathrm{NGF}$ and then fixed. The morphologies of the growth cones under the indicated culture conditions were scored blind from coded samples and were designated as either extended or collapsed. The values represent averages of determinations on duplicate cultures (>100 growth cones scored per culture), and error bars indicate range. Comparable results were obtained in an additional independent experiment.

\section{KT5926 does not affect the overall NGF signaling mechanism}

It has been reported that $\mathrm{K}-252 \mathrm{a}$ is a potent and specific inhibitor of NGF-stimulated gp140 protork tyrosine kinase activity (Berg et al., 1992; Nye et al., 1992) and consequently blocks all responses of PC12 cells to NGF (Koizumi et al., 1988). Since KT5926 is an $n$-propoxy derivative of K-252a (Nakanishi et al., 1990), it is conceivable that this compound may affect NGFdependent neurite outgrowth by a similar mechanism involving the tyrosine kinase activity of the receptor. Therefore, we ex- amined the ability of NGF to induce autophosphorylation of gp 140 ${ }^{\text {prototrk }}$ (Kaplan et al., 1991; Loeb et al., 1991) in cells that had been pretreated with KT5926. Replicate cultures of naive cells were pretreated with either $200 \mathrm{nM} \mathrm{K}-252$ a for 20 min or $6 \mu \mathrm{M}$ KT5926 for $24 \mathrm{hr}$, and then exposed to NGF for $10 \mathrm{~min}$ in the continuous presence of the respective inhibitors. The cells were then lysed and subjected to immunoprecipitation with anti-gp 140 protork antiserum. The immunoprecipitates were analyzed by Western immunoblotting with anti-phosphotyrosine antibodies. The results are shown in Figure 6. Consistent with 


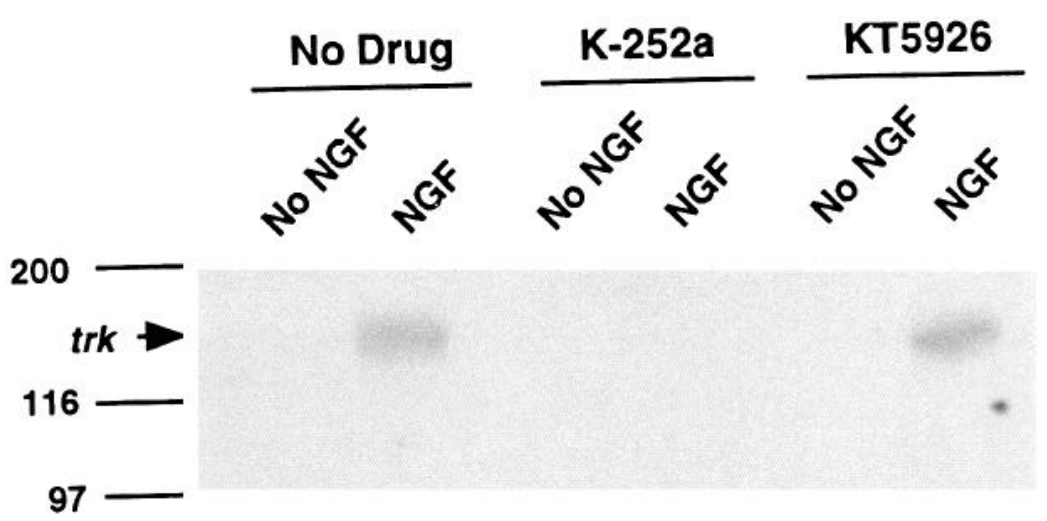

Figure 6. NGF-induced gp140 protork autophosphorylation in KT5926-treated cells. PC12-C41 cells were pretreated either with $6 \mu \mathrm{M}$ KT5926 for $16 \mathrm{hr}$ or with $200 \mathrm{nM} \mathrm{K}-252 \mathrm{a}$ for $20 \mathrm{~min}$. NGF $(100 \mathrm{ng} / \mathrm{ml}$ final concentration) was added to the culture medium for $5 \mathrm{~min}$ in the presence of the respective inhibitors. Control cultures that received no drug pretreatment were similarly exposed to $100 \mathrm{ng} / \mathrm{ml} \mathrm{NGF}$. Equal concentrations of protein from each culture (adjusted to equal final volume) were subjected to immunoprecipitation with gp140protork antiserum. The immunoprecipitates were resolved by SDS-PAGE and subjected to Western immunoblotting with anti-phosphotyrosine antibodies. Conditions for inhibitor and/or NGF treatment are shown at the top. Numbers on the left indicate the positions of molecular mass standards $\left(M, \times 10^{-3}\right)$. Arrow indicates the position of gp140 prototrk $(t r k)$.

previous reports (Berg et al., 1992; Nye et al., 1992), 200 nм $\mathrm{K}-252 \mathrm{a}$ completely inhibits the NGF-dependent autophosphorylation of gp $140^{\text {protork. }}$. In contrast, the NGF-induced autophosphorylation of gp $140^{\text {prototrk }}$ was not affected by $6 \mu \mathrm{M}$ KT5926.

To determine if KT5926 might significantly alter early downstream elements of the NGF signaling mechanism, we examined c-fos mRNA induction, which constitutes part of the early $\mathrm{PC} 12$ and PC12-C41 cellular responses to NGF (Greenberg et al., 1985; Teng et al., 1993). Figure 7 shows a Northern blot depicting the time courses of c-fos mRNA induction by NGF in cells with or without KT5926 pretreatment. The data show that NGF causes a rapid and transient upregulation of c-fos mRNA in the KT5926-treated cells. The magnitude and kinetics of induction are indistinguishable from those in control cultures (without exposure to KT5926). Furthermore, the subsequent downregulation of c-fos mRNA is not affected by the presence of KT5926. Consistent with these findings, the NGF-dependent induction of another immediate-early gene, Tis- 1 (Kujubu et al., 1987), is also unaffected by KT5926 (data not shown).

\section{KT5926 does not affect the phosphorylation of known NGF- regulated cytoskeletal proteins}

Much evidence indicates that the cytoskeleton plays a critical role in NGF-induced neuritogenesis (Aletta et al., 1990). In particular, past studies have shown a correlation between NGFdependent neuritic outgrowth and the phosphorylation of $\beta$-tubulin (Black et al., 1986; Aletta and Greene, 1987) and specific MAPs such as chartins (Black et al., 1986; Aletta and Greene, 1987) and MAP 1.2/1B (Greene et al., 1983; Aletta et al., 1988). Because KT5926 is a protein kinase inhibitor and suppresses neurite outgrowth, we sought to determine whether this compound might inhibit the phosphorylation of specific cytoskeletal components. To test this possibility, naive or long-term $(>10$

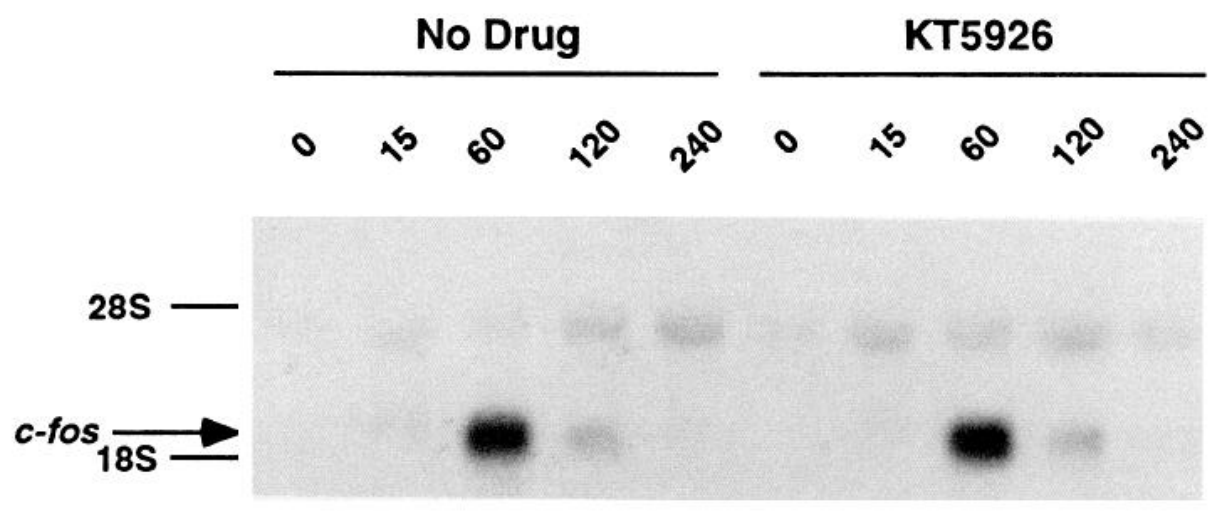

Figure 7. Induction of c-fos mRNA by NGF in KT5926-treated cell cultures. Replicate PC12-C41 cell cultures were pretreated overnight with 5 $\mu \mathrm{M}$ KT5926 and then exposed to $100 \mathrm{ng} / \mathrm{ml} \mathrm{NGF}$ for the indicated times in the continued presence of the inhibitor. Replicate control cultures without KT5926 exposure were similarly treated with NGF. Total cellular RNA from each condition was isolated and subjected to Northern blotting analysis. Equal amounts $(10 \mu \mathrm{g})$ of RNA were hybridized to a ${ }^{32} \mathrm{P}$-labeled probe for c-fos. The durations of NGF exposure (in minutes) and culture conditions are indicated at the top. Positions of the $28 \mathrm{~S}$ and $18 \mathrm{~S}$ rRNAs are shown on the left, as is the position of c-fos message. The 6 kilobase RNA species (above the c-fos signal) was found to hybridize with a probe for the neomycin resistance gene and represents a crosshybridization between the c-fos probe and the sequence of the retroviral vector used to generate the PC12-C41 cell line (data not shown). Comparable results were obtained in an additional independent experiment. 
A

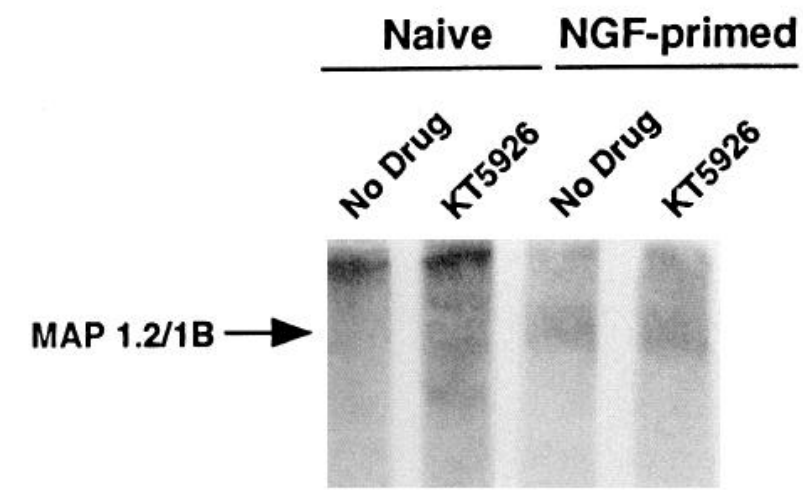

B

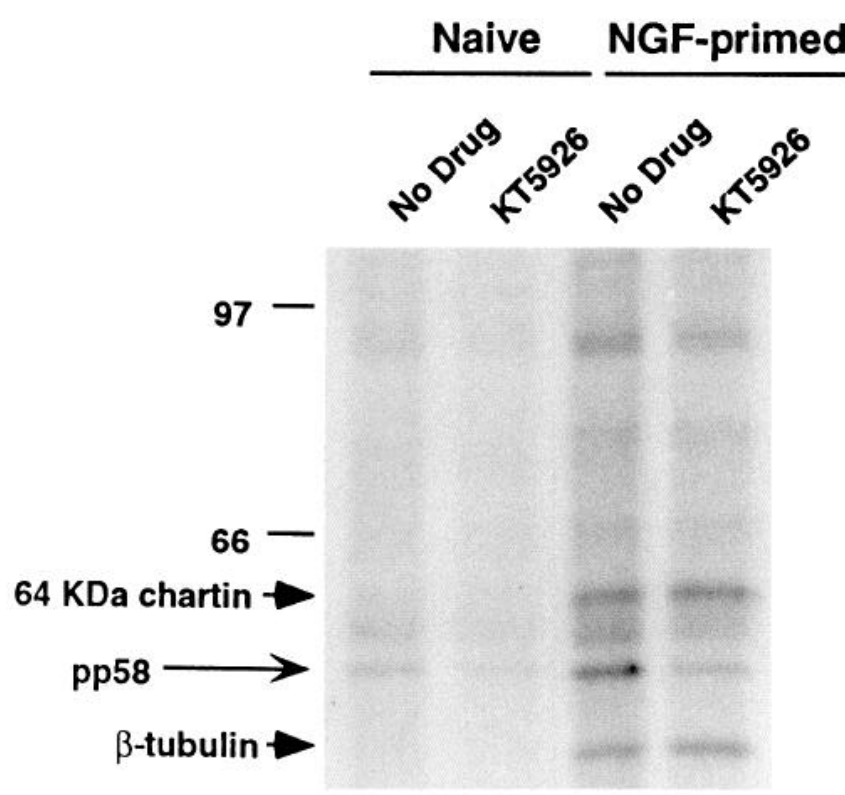

Figure 8. Phosphorylation of cytoskeletal proteins in KT5926-treated cell cultures. $A$, Total cell protein and MAP 1.2/1B phosphorylation. Naive or long-term (22 d) NGF-primed PC12-C41 cells were treated overnight with $6 \mu \mathrm{M}$ KT5926. Each culture was labeled (in the continued presence of drug) with $50 \mu \mathrm{Ci} / \mathrm{ml}{ }^{32} \mathrm{P}$-orthophosphate for $3 \mathrm{hr}$. Total cellular extracts were prepared and equal trichloroacetic acid (TCA)precipitable counts per sample were analyzed by SDS-PAGE (see Materials and Methods). The treatment conditions are shown at the top and the position of phosphorylated MAP $1.2 / 1 \mathrm{~B}$ is indicated on the left (arrow). All samples were from a single autoradiogram but were rearranged for clarity of presentation. Three independent experiments yielded comparable results. $B$, Phosphorylation of $\beta$-tubulin, chartin MAPs, and other $\mathrm{Ca}^{2+}$-releasable cytoskeletal proteins. Replicate cultures of naive or NGF-primed (22 d) PC12-C41 cells were pretreated overnight with $5 \mu \mathrm{M}$ KT5926. The cultures were then labeled (in the continued presence of drug) with $300 \mu \mathrm{Ci} / \mathrm{ml}{ }^{32} \mathrm{P}$-orthophosphate for $3 \mathrm{hr}$. Subcellular fractionations were performed as described (Aletta and Greene, 1987; Teng and Greene, 1993) and the $\mathrm{Ca}^{2+}$-releasable MAP fraction d) NGF-treated cultures were exposed to $5 \mu \mathrm{M}$ KT5926 for 16 $20 \mathrm{hr}$, and then labeled with ${ }^{32} \mathrm{P}$-orthophosphate for $2-4 \mathrm{hr}$. Both whole-cell extracts and fractions enriched in $\mathrm{Ca}^{2+}$-releasable MAPs (released by $\mathrm{Ca}^{2+} /$ cold from cells preextracted with Triton in an microtubule-stabilizing buffer; see Materials and Methods) were prepared and analyzed by SDS-PAGE and autoradiography. Representative autoradiograms are shown in Figure 8 . The data reveal that KT5926 exerts no appreciable effect on the phosphorylation states of $\beta$-tubulin (Fig. $8 \mathrm{~A}$ ), the chartin MAPs (Fig. $8 A$ ), or MAP 1.2/1B (Fig. $8 B$ ).

\section{KT5926 specifically reduces the phosphorylation level of pp58}

Despite the lack of effect of KT5926 on known NGF-regulated cytoskeletal phosphoproteins, the labeling of an unidentified phosphoprotein of apparent $M_{r} 58,000$ (pp58) in the $\mathrm{Ca}^{2+}$-releasable/MAP fractions of naive and NGF-treated cells is markedly reduced by this compound (Fig. $8 B$ ). Scanning densitometry of a large number of independent experiments $(n=6)$ revealed that upon KT5926 exposure, pp58 labeling decreased by $36 \pm 10 \%$ and $60 \pm 16 \%$ in naive and NGF-primed cultures, respectively. In consonance with a previous report (Teng and Greene, 1993), labeling of pp58 is slightly increased $(\approx 30 \%)$ by NGF.

We next determined the relative phosphorylation of $\mathrm{pp} 58$ after short-term exposure to KT5926. Replicate cultures of naive and long-term ( $>10 \mathrm{~d}) \mathrm{NGF}$-primed cells were labeled with ${ }^{32} \mathrm{P}$-orthophosphate, treated with $5 \mu \mathrm{M}$ KT5926 for $15 \mathrm{~min}$ or $2 \mathrm{~d}$, extracted for $\mathrm{Ca}^{2+}$-releasable/MAPs, and analyzed by SDSPAGE and autoradiography. The results (Fig. $9 A$ ) indicate that $5 \mu \mathrm{M}$ KT5926 significantly decreases the phosphate labeling of pp58 in both naive and NGF-treated cells after only $15 \mathrm{~min}$ of treatment. As noted above, the phosphorylations of $\beta$-tubulin and chartins are not affected by this compound at both time points. Examination of the Triton-soluble fraction recovered from the same sets of cells reveals no effect on the vast majority of phosphate-labeled proteins with the consistent exception of a small reduction in labeling of a band that comigrates with pp58 (data not shown). Finally, the phosphoprotein labeling in the insoluble fractions (i.e., cellular materials remaining after the Triton and $\mathrm{Ca}^{2+}$ extractions) from KT5926-treated and control cultures is indistinguishable (K. K. Teng and L. A. Greene, unpublished observation). Thus far, therefore, the decrease in relative labeling of pp58 represents the only phosphorylation difference we have consistently detected by SDS-PAGE in cultures treated with KT5926.

The effects of KT5926 do not appear due to inhibition of myosin light chain kinase and/or calmodulin-dependent kinase II

Past work has indicated that KT5926, at concentrations similar to those used in this study, is an effective inhibitor of both MLCK (Nakanishi et al., 1990) and CamKII (Hashimoto et al.,

from each culture condition (equal TCA-precipitable cpm) was resolved by SDS-PAGE on a $5-10 \%$ acrylamide gradient gel. Treatment conditions are indicated at the top and the relative migrations of the molecular mass standards (as $M_{r} \times 10^{-3}$ ) are shown on the left. Arrows mark the positions of phosphorylated $64 \mathrm{kDa}$ chartin MAP and $\beta$-tubulin, respectively. The position of a KT5926-sensitive phosphoprotein at 58 $\mathrm{kDa}(\mathrm{pp} 58)$ is also indicated by an arrow. The order of the samples within a single experiment was rearranged for clarity of presentation. Similar results were obtained in two additional experiments. 

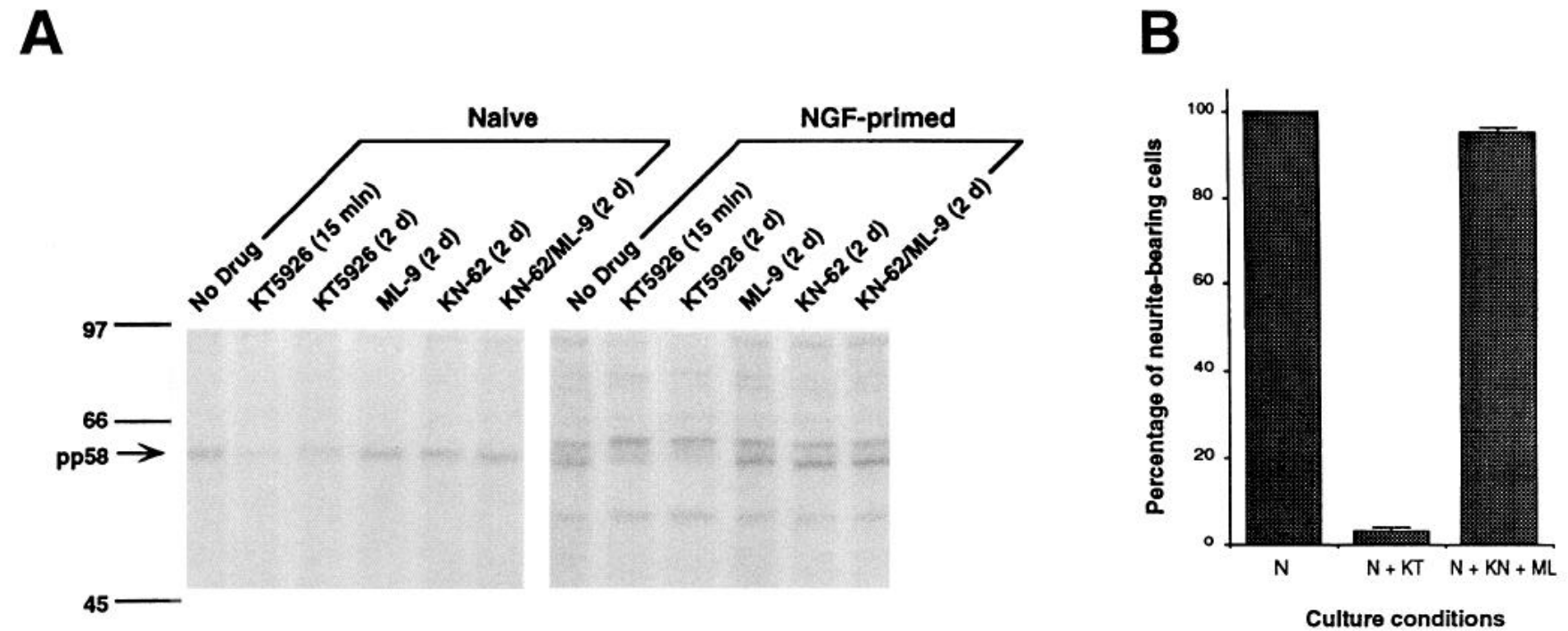

Figure 9. Comparative effects of KT5926, KN-62, and ML-9 on phosphoprotein composition and on inhibition of neurite outgrowth. A, Rapid and specific inhibition of pp 58 phosphorylation in the $\mathrm{Ca}^{2+}$-releasable MAP fraction. Naive or long-term (25 d) NGF-treated PC12-C41 cells were treated during the last $2 \mathrm{~d}$ of culture with either $5 \mu \mathrm{M}$ KT5926, $10 \mu \mathrm{M} \mathrm{KN}-62,10 \mu \mathrm{M}$ ML-9, or $10 \mu \mathrm{M}$ each of KN-62 and ML-9. The cultures were then labeled with $300 \mu \mathrm{Ci} / \mathrm{ml}^{32} \mathrm{P}$-orthophosphate for $3 \mathrm{hr}$ in the presence of the respective drugs. In addition, replicate cultures of naive and NGFtreated PC12-C41 cells were exposed to $5 \mu \mathrm{M}$ KT5926 during the last $15 \mathrm{~min}$ of labeling. The $\mathrm{Ca}^{2+}$-releasable MAPs fraction from each culture was prepared and equal cpm of TCA-precipitable materials were analyzed by SDS-PAGE and autoradiography. The treatment condition for each culture is indicated at the top. Numbers on the left show the positions of molecular mass standards (as $M, \times 10^{-3}$ ). The arrow marks the position of pp58. All samples were from a single autoradiogram but were rearranged for clarity of presentation. Comparable results were obtained in two additional experiments. B. Specific inhibition of neurite outgrowth by KT5926. Replicate cultures of PC12-C41 cells were treated with $100 \mathrm{ng} / \mathrm{ml}$ NGF $(N)$ for $14 \mathrm{~d}$ in the absence or presence of either $5 \mu \mathrm{M} \mathrm{KT5926}(K T)$ or $10 \mu \mathrm{M} \mathrm{KN}-62$ and $10 \mu \mathrm{M}$ ML-9 $(K N+M L)$, as indicated. The proportion of neurite-bearing cells under each culture condition was then determined. The results represent means \pm SEM of three independent determinations.

1991). We therefore examined whether other inhibitors of these two protein kinases might similarly affect the phosphorylation of pp58. As shown in Figure 9A, $10 \mu \mathrm{M}$ ML-9 and KN-62 [cellpermeant specific inhibitors of MLCK (Ishikawa et al., 1988; Baorto et al., 1992) and CamKII (Tokumitsu et al., 1990; Ishii et al., 1991), respectively], when administered either separately or together, fail to decrease the relative phosphorylation of pp 58 in naive or NGF-primed cultures. Furthermore, neither ML-9 nor KN-62 (each at $10 \mu \mathrm{M}$ ) alone (data not shown) or in combination (Fig. 9B) significantly inhibit NGF-induced neuritogenesis.

\section{Discussion}

\section{Differential inhibition of NGF-promoted neurite elongation by} KT5926

The present study investigates the effects of the protein kinase inhibitor KT5926 on cellular responses to NGF. Our data show that at low micromolar concentrations, KT5926 significantly prevents NGF-promoted neuritogenesis and neurite regeneration by $\mathrm{PC} 12$ and $\mathrm{PC} 12-\mathrm{C} 41$ cells. This suppression of neuritic outgrowth persists while the inhibitor is present and reverses upon its removal.

In contrast to its actions on neurites, KT5926 does not significantly alter other NGF responses, including gp $140^{\text {prototrk }}$ autophosphorylation, c-fos and Tis- 1 mRNA induction, or phosphorylation of MAPs and $\beta$-tubulin. Moreover, KT5926 does not appear to interfere with NGF-promoted priming. "Priming" is a transcription-dependent process that appears to be due to the synthesis and accumulation of specific molecules required for neurite outgrowth (Greene, 1984). These results therefore indicate that KT5926 inhibits a transcription-independent com- ponent of neuritogenesis. Of relevance to this, KT5926 treatment does not result in degeneration or withdrawal of neurites as occurs in response to NGF removal (Greene and Tischler, 1976; Teng and Greene, 1993), but rather affects their ability to elongate (Fig. 4). This strongly suggests a specific interference by this compound with the NGF-regulated cellular machinery for neurite extension.

Growth cone spreading and motility are major components of the neurite extension machinery that are regulated by NGF in a transcription-independent manner (Seeley and Greene, 1983; Connolly et al., 1985, 1987). Our data indicate that KT5926 causes preexisting, spread growth cones to attain a stubby, "collapsed" shape. In addition, this drug also prevents the reactivation of NGF-deprived growth cones that occurs upon NGF readdition. Prior studies (Seeley and Greene, 1983; Aletta and Greene, 1988) have indicated that spread growth cones are motile and locomotive, whereas those in the collapsed conformation are nonmotile and do not advance. These results therefore reveal an inhibitory action of KT5926 on NGF-regulated growth cone behavior and suggest an attractive locus for the differential effect of this compound on neurite outgrowth. However, presently available information does not distinguish whether growth cone function represents the primary cellular target of KT5926, whether growth cone activity represents only one of multiple actions affected by this compound, or whether the observed growth cone effects represent secondary, indirect consequences of other actions of this drug.

\section{Mechanistic considerations}

KT5926 is structurally similar to a series of potent protein kinase inhibitors that includes the compounds K-252a and stau- 
rosporine (reviewed by Knüsel and Hefti, 1992). KT5926 has itself been shown to be a potent protein kinase inhibitor that blocks MLCK (Nakanishi et al., 1990) and CamKII (Hashimoto et al., 1991) in vitro. Thus, it seems highly likely that the capacity of this drug to suppress NGF-promoted neuritogenesis is attributable to its kinase inhibitory activity. A number of compounds have been identified that inhibit neurite outgrowth from NGF-treated PC12 cells and many of these are also blockers of protein kinase activity. KT5926, however, seems distinct in site of action from such agents. For instance, our data show that KT5926 clearly contrasts with K-252a (Knüsel and Hefti, 1992), which blocks all actions of NGF (Koizumi et al., 1988) and appears to do so by selectively inhibiting the tyrosine kinase activity of the gp 140 protorrk NGF receptor (Berg et al., 1992; Nye et al., 1992). KT5926 is also distinct from $5^{\prime}$ - $S$-methyl adenosine, which blocks all NGF responses (Seeley et al., 1984). Moreover, unlike 2-aminopurine, which blocks at least several protein kinases (Volonté and Greene, 1992), or 6-thioguanine, which selectively inhibits the NGF-activated protein kinase $\mathrm{N}$ (Volonté et al., 1989), KT5926 does not appear to affect the induction of immediate-early genes by NGF (Batistatou et al., 1992; present study). In addition, KT5926 differs from inhibitors of protein tyrosine kinase, such as genistein, which promote neurite outgrowth in the absence of NGF (Miller et al., 1993). Finally, although KT5926 appears to resemble $\mathrm{Li}^{+}$(Burstein et al., 1985) in selectively affecting neurite outgrowth, it is distinct in mechanism in that it does not suppress phosphorylation of the chartin MAPs.

While past work has indicated that KT5926 inhibits MLCK (Nakanishi et al., 1990) and CamKII (Hashimoto et al., 1991) in selective cell types, these activities do not appear to account for the capacity of this compound to suppress neurite outgrowth. We found that other well-characterized inhibitors of MLCK and CamKII [ML-9 (Ishikawa et al., 1988; Baorto et al., 1992) and KN-62 (Tokumitsu et al., 1990; Ishii et al., 1991), respectively] display no demonstrable effects on NGF-promoted ncuritogenesis. Previous studies (Tokumitsu et al., 1990; Ishii et al., 1991) reported that $\mathrm{KN}-62$ (at concentrations similar or lower than that used here) effectively abolishes CamKII-dependent responses in PC12 cells. Similarly, studies regarding ML-9 or its inhibition of MLCK indicated that this compound is quite effective in a variety of cell types (Ishikawa et al., 1988; Baorto et al., 1992). Moreover, the calmodulin antagonist calmidazolium (which would also be expected to suppress CamKII and MLCK activities; Van Belle, 1981; Sobieszek, 1989; Bading et al., 1993) does not appear to affect NGF-promoted neurite growth substantially (K. K. Teng, unpublished observations). These considerations thus suggest that KT5926 prevents neuritogenesis independently from its actions on CamKII and MLCK. This is further supported by our observation that unlike KT5926, $\mathrm{KN}-62$ and ML-9 do not affect the phosphate labeling of pp58. The ability of compounds such as KT5926 to inhibit activities other than, or in addition to, those defined in vitro has a precedence. K-252a was initially defined in vitro as a selective protein kinase C inhibitor (Kase et al., 1986) but, as noted above, was subsequently shown to inhibit gp 140 prototr tyrosine kinase activity in intact cells (Berg et al., 1992; Nye et al., 1992). Finally, like K-252a (Koizumi et al., 1988) and a structurally similar compound, staurosporine (Ilashimoto and Hagino, 1989), KT5926 does not exert an inhibitory effect on basic fibroblast growth factor-induced neurite outgrowth from PC12 or PC12C41 cells. Taken together, our results suggest that KT5926 may suppress NGF-regulated neurite outgrowth via inhibition of a hitherto unidentified protein kinase.

\section{KT5926 and pp.58}

The most salient effect of KT5926 on PC12-C41 cell phosphoproteins was to diminish the phosphate labeling of a $58 \mathrm{kDa}$ component. This change occurred among a background of at least 30 other species whose incorporation of phosphate was unaffected by KT5926. Preliminary experiments have also revealed that KT5926 has no effect on the vast majority of phosphoproteins resolved by two-dimensional isoelectric focusing $x$ SDS-PAGE (K. K. Teng and J. M. Angelastro, unpublished observations) or on proteins from NGF-treated cells detected with anti-phosphotyrosine antibody in Western immunoblots (Teng, unpublished observations). Thus, KT5926 is not a general inhibitor of protein phosphorylation and its actions therefore appear to affect at most a restricted subset of cell phosphoproteins. This is consistent with the suggestion that the biologically relevant target of KT5926 is a protein kinase with a limitcd number of substrates.

Although the identity of pp58 is presently unclear, subcellular fractionation indicates its presence in both Triton-soluble and $\mathrm{Ca}^{2+}$-releasable/MAP fractions (predominantly in the latter fraction). This distribution distinguishes $\mathrm{pp} 58$ from tyrosine hydroxylase, a major soluble phosphoprotein of PC12 cells of apparent $M_{r} 59-60 \mathrm{kDa}$ (Nose et al., 1985). We do not presently know whether the effects of KT5926 on pp58 are causally related to the actions of this drug on neurite outgrowth. Recently, we reported that elevated $\mathrm{K}^{+}$prevents neurites of NGF-deprived PC12 and PC12-C41 cells from degenerating, but that these depolarization-maintained neurites do not continue to elongate (Teng and Greene, 1993). Of possible relevance here, under such culture conditions, the phosphorylation of pp 58 was also reduced (Teng and Greene, 1993).

In conclusion, we have shown here that the protein kinase inhibitor KT5926 differentially suppresses NGF-dependent neurite outgrowth and affects growth cone functions. This drug appears to mediate its actions via novel cellular targets that include pp58. It is quite conceivable that additional KT5926sensitive proteins remain to be detected and that one or more of these plays a critical functional role in neurite outgrowth.

\section{References}

Aletta JM, Greene LA (1987) Sequential phosphorylation of chartin microtubule-associated proteins is regulated by the presence of $\mathrm{mi}$ crotubules. J Cell Biol 105:277-290.

Aletta JM, Greene LA (1988) Growth cone configuration and advance: a time-lapse study using video-enhanced differential interference contrast microscopy. J Neurosci 8:1425-1435.

Aletta JM, Lewis SA, Cowan NJ, Greene LA (1988) Nerve growth factor regulates both the phosphorylation and steady-state levels of microtubule-associated protein 1.2 (MAP 1.2). J Cell Biol 106:15731581 .

Aletta JM, Shelanski ML, Greene LA (1989) Phosphorylation of the peripherin $58-\mathrm{kDa}$ neuronal intermediate filament protein: regulation by nerve growth factor and other agents. J Biol Chem 264:4619-4627.

Aletta JM, Tsao H, Greene LA (1990) How do neurites grow? Clues from NGF-regulated cytoskeletal phosphoproteins. In: Trophic factors and the nervous system (Horrocks LA, ed), pp 203-218. New York: Raven.

Bading H, Ginty DD, Greenberg ME (1993) Regulation of gene expression in hippocampal neurons by distinct calcium signaling pathways. Science 260:181-186.

Baorto DM, Mellado W, Shelanski ML (1992) Astrocyte process growth induction by actin breakdown. J Cell Biol 117:357-367.

Batistatou A, Volonté C, Greene LA (1992) Nerve growth factor em- 
ploys multiple pathways to induce primary response genes in $\mathrm{PC} 12$ cells. Mol Biol Cell 3:363-371.

Berg MM, Sternberg DW, Parada LF, Chao MV (1992) K-252a inhibits nerve growth factor-induced $t r k$ proto-oncogene tyrosine phosphorylation and kinase activity. J Biol Chem 267:13-16.

Black MM, Aletta JM, Greene LA (1986) Regulation of microtubule composition and stability during nerve growth factor-promoted neurite outgrowth. J Cell Biol 103:545-557.

Bradford MM (1976) A rapid and sensitive method for the quantitation of microgram quantities of protein utilizing the principle of protein-dye binding. Anal Biochem 72:248-252.

Burstein DE, Greene LA (1978) Evidence for RNA synthesis-dependent and -independent pathways in stimulation of neurite outgrowth by nerve growth factor. Proc Natl Acad Sci USA 75:6059-6063.

Burstein DE, Seeley PJ, Greene LA (1985) Lithium ion inhibits nerve growth factor-induced neurite outgrowth and phosphorylation of nerve growth factor-modulated microtubule-associated proteins. J Cell Biol 101:862-870.

Chomczynski P, Sacchi N (1987) Single-step method of RNA isolation by acid guanidinium thiocyanate-phenol-chloroform extraction. Anal Biochem 162:156-159.

Connolly JL, Seeley PJ, Greene LA (1985) Regulation of growth cone morphology by nerve growth factor: a comparative study by scanning electron microscopy. J Neurosci Res 13:183-198.

Connolly JL, Seeley PJ, Greene LA (1987) Rapid regulation of neuronal growth cone shape and surface morphology by nerve growth factor. Ncurochem Res 12:861-868.

Curran T, Peters G, Van Beveren C, Teich NM, Verma IM (1982) FBJ murine osteosarcoma virus: identification and molecular cloning of biologically active proviral DNA. J Virol 44:674-682.

Dickson G, Prentice H, Julien J, Ferrari G, Leon A, Walsh FS (1986) Nerve growth factor activates Thy-1 and neurofilament gene transcription in rat PCl 2 cells. EMBO J 5:3349-3353.

Ebendal T (1992) Function and evolution in the NGF family and its receptors. J Neurosci Res 32:461-470.

Greenberg ME, Greene LA, Ziff EB (1985) Nerve growth factor and epidermal growth factor induce rapid transient changes in proto-oncogene transcription in PC.12 cells. J Biol Chem 260:14101-14110.

Greene LA (1984) The importance of both early and delayed responses in the biological actions of nerve growth factor. Trends Neurosci 7:9194.

Greene LA, Tischler AS (1976) Establishment of a noradrenergic clonal line of rat adrenal pheochromocytoma cells which respond to nerve growth factor. Proc Natl Acad Sci USA 73:2424-2428.

Greene LA, Tischler AS (1982) PC12 pheochromocytoma cultures in neurobiological research. Adv Cell Neurobiol 3:373-414.

Greene LA, Burstein DE, Black MM (1982) The role of transcriptiondependent priming in nerve growth factor promoted neurite outgrowth. Dev Biol 91:305-316.

Greene LA, Liem RKH, Shelanski ML (1983) Regulation of a high molecular weight microtubule-associated protein in $\mathrm{PC} 12$ cells by nerve growth factor. J Cell Biol 103:76-83.

Greene LA, Aletta JM, Rukenstein A, Green SH (1987) PC12 pheochromocytoma cells: culture, nerve growth factor treatment, and experimental exploitation. Methods Enzymol 147:207-216.

Greene LA, Sobeih MM, Teng KK (1991) Methodologies for the culture and experimental use of the $\mathrm{PC} 12$ rat pheochromocytoma cell line. In: Culturing nerve cells (Banker G, Goslin K, eds), pp 207-226. Cambridge, MA: MIT Press.

Halegoua S, Armstrong RC, Kremer NE (1991) Dissecting the mode of action of a neuronal growth factor. Curr Top Microbiol Immunol 165:119-170.

Hashimoto S, Hagino A (1989) Blockage of nerve growth factor action in $\mathrm{PC} 12 \mathrm{~h}$ cells by staurosporine, a potent protein kinase inhibitor. $\mathrm{J}$ Neurochem 53:1675-1685.

Hashimoto $\mathrm{Y}$, Nakayama T, Teramoto $\mathrm{T}$, Kato $\mathrm{H}$, Watanabe T, Kinoshita $M$, Tsukamoto $K$, Tokunaga $K$, Kurokawa K, Nakanishi S, Matsuda Y, Nonomura Y (1991) Potent and preferential inhibition of $\mathrm{Ca}^{+2} / \mathrm{calmodulin}$-dependent protein kinase II by $\mathrm{K}-252 \mathrm{a}$ and its derivative, KT5926. Biochem Biophys Res Commun 181:423-429.

Ishii A, Kiuchi K, Kobayashi R, Sumi M, Hidaka H, Nagatsu T (1991) A selective $\mathrm{Ca}^{+2} /$ calmodulin-dependent protein kinase II inhibitor, $\mathrm{KN}-62$, inhibits the enhanced phosphorylation and the activation of tyrosine hydroxylase by $56 \mathrm{mM} \mathrm{K}^{+}$in rat pheochromocytoma $\mathrm{PC} 12 \mathrm{~h}$ cells. Biochem Biophys Res Commun 176:1051-1056.
Ishikawa T, Chijiwa T, Hagiwara M, Mamiya S, Saitoh M, Hidaka $\mathrm{H}$ (1988) ML-9 inhibits the vascular contraction via the inhibition of myosin light chain kinase. Mol Pharmacol 33:598-603.

Kaplan DR, Morrison DK, Wong G, McCormick F, Williams LT (1990) PDGF $\beta$-receptor stimulates tyrosine phosphorylation of GAP and association of GAP with a signaling complex. Cell 61:125-133.

Kaplan DR, Hempstead BL, Martin-Zanca D, Chao MV, Parada LF (1991) The $t r k$ proto-oncogene product: a signal transducing receptor for nerve growth factor. Science 252:554-558.

Kase H, Iwahashi K, Matsuda Y (1986) K-252a, a potent inhibitor of protein kinase $C$ from microbial origin. J Antibiot 39:1059-1065.

Knüsel B, Hefti F (1992) K-252 compounds: modulators of neurotrophin signal transduction. J Neurochem 59:1987-1996.

Koizumi S, Contreras ML, Matsuda Y, Hama T, Lazarovici P, Guroff $G$ (1988) K-252a: a specific inhibitor of the action of nerve growth factor on PC12 cells. J Neurosci 8:715-721.

Kujubu DA, Rim RW, Varnum BC, Herschman HR (1987) Induction of transiently expressed genes in PC12 pheochromocytoma cells. Oncogene 1:257-262.

Laemmli UK (1970) Cleavage of structural protein during the assembly of the head of bacteriophage T4. Nature 227:680-685.

Leonard DGB, Gorham JD, Cole P, Greene LA, Ziff EB (1988) A nerve growth factor-regulated messenger RNA encodes a new intermediate filament protein. J Cell Biol 106:181-193.

Levi A, Alemá S (1991) The mechanism of action of nerve growth factor. Annu Rev Pharmacol Toxicol 31:205-228.

Levi-Montalcini R, Angeletti PU (1968) Nerve growth factor. Physiol Rev 48:534-569.

Loeb DM, Maragos J, Martin-Zanca D, Chao MV, Parada LF, Greene LA (1991) The trk proto-oncogene rescues NGF responsiveness in mutant NGF-nonresponsive PC12 cell line. Cell 66:961-966.

Loeb DM, Tsao H, Cobb MH, Greene LA (1992) NGF and other growth factors induce an association between ERKI and the NGF receptor, gp 140 prototr. Neuron 9:1053-1065.

Miller DR, Lee GM, Maness PF (1993) Increased neurite outgrowth induced by inhibition of protein tyrosine kinase activity in $\mathrm{PCl} 2$ pheochromocytoma cells. J Neurochem 60:2134-2144.

Mobley WC, Schenker A. Shooter EM (1976) Characterization and isolation of proteolytically modified nerve growth factor. Biochemistry 15:5543-5552.

Nakanishi S, Yamada K, Iwahashi K, Kuroda K, Kase H (1990) KT5926, a potent and selective inhibitor of myosin light chain kinase. Mol Pharmacol 37:482-488.

Noble M, Lewis SA, Cowan NJ (1989) The microtubule binding domain of microtubule-associated protein MAP1B contains a repeated sequence motif unrelated to that of MAP2 and tau. J Cell Biol 109: 3367-3376.

Nose PS, Griffith LC, Schulman H (1985) $\mathrm{Ca}^{2+}$-dependent phosphorylation of tyrosine hydroxylase in PC12 cells. J Cell Biol 101: $1182-1190$.

Nye SH, Squinto SP, Glass DJ, Stitt TN, Hantzopoulos P, Macchi MJ, Lindsay NS, Ip NY, Yancopoulos GD (1992) K-252a and staurosporine selectively block autophosphorylation of neurotrophin receptors and neurotrophin-mediated responses. Mol Biol Cell 3:677-686.

Prentice HM, Moore SE, Dickson JG, Doherty P, Walsh FS (1987) Nerve growth factor-induced changes in neural cell adhesion molecule (N-CAM) in PC12 cells. EMBO J 6:1859-1863.

Scclcy PJ, Grecnc LA (1983) Short latency local actions of nerve growth factor at the growth cone. Proc Natl Acad Sci USA 80:27892793.

Seeley PJ, Rukenstein A, Connolly JL, Greene LA (1984) Nerve growth factor and epidermal growth factor effects on the PC12 pheochromocytoma line. J Cell Biol 98:417-426.

Sobieszek A (1989) Calmodulin antagonist action in smooth-muscle myosin phosphorylation. Biochem J 262:215-223.

Solomon F, Magendantz M, Salzman A (1979) Identification with cellular microtubules of one of the co-assembly microtubule-associated proteins. Cell 18:431-438.

Soltoff SP, Rabin SL, Cantley LC, Kaplan DR (1992) Nerve growth factor promotes the activation of phosphatidylinositol 3-kinase and its association with the trk tyrosine kinase. J Biol Chem 267:1747217477 .

Teng KK, Greene LA (1993) Depolarization maintains neurites and priming of PC 12 cells after nerve growth factor withdrawal. J Neurosci 13:3124-3135. 
Teng KK, Georgieff IS, Aletta JM, Nunez J, Shelanski ML, Greene LA (1993) Characterization of a $\mathrm{PCl} 2$ cell sub-clone (PC12-C41) with enhanced neurite outgrowth capacity: implications for a modulatory role of high molecular weight tau in neuritogenesis. J Cell Sci 106: 611-626.

Tokumitsu H, Chijiwa T, Hagiwara M, Mizutani A, Terasawa M, Hidaka $\mathrm{H}$ (1990) $\mathrm{KN}-62,1$-[ $N, O$-bis(5-isoquinolinesulfony)- $N$-methyl-L-tyrosyl]-4-phenylpiperazine, a specific inhibitor of $\mathrm{Ca}^{+2} / \mathrm{calmo}^{-}$ dulin-dependent protein kinase II. J Biol Chem 265:4315-4320.

Towbin H, Staehlin T, Gordon J (1979) Electrophoretic transfer of proteins from polyacrylamide gels to nitrocellulose sheets: procedure and some applications. Proc Natl Acad Sci USA 76:4350-4354.

Van Belle H (1981) R 24 571: a potent inhibitor of calmodulin-activated enzymes. Cell Calcium 2:483-494.
Volonté C, Greene LA (1992) 6-Methylmercaptopurine riboside is a potent and selective inhibitor of nerve growth factor-activated protein kinase N. J Neurochem 58:700-708.

Volonté C, Rukenstein A, Loeb DM, Greene LA (1989) Differential inhibition of nerve growth factor responses by purine analogues: correlation with inhibition of a nerve growth factor-activated protein kinase. J Cell Biol 109:2395-2403.

Weinberger RP, Henke RC, Tolhurst O, Jeffrey PL, Gunning P (1993) Induction of neuron-specific tropomyosin mRNAs by nerve growth factor is dependent on morphological differentiation. J Cell Biol 120 205-215. 